\title{
SEASONAL LARVAL ABUNDANCE OF THE BLACKFLY, SIMULIUM DAMNOSUM COMPLEX AND THE PHYSICO-CHEMICAL PROPERTIES OF THEIR BREEDING SITES IN OJI RIVER SYSTEM, ENUGU STATE, NIGERIA
}

\author{
Josephine Chiogo Ochu' ${ }^{1}$, Ethel-Doris N. Umeh ${ }^{2}$ and Victor S. Njom ${ }^{3}$
}

${ }^{1}$ Federal Ministry of Health, National Arbovirus and Vectors Research Centre (NAVRC), Enugu, Nigeria. E-mail address - (chio4ever2005@yahoo.com).

${ }^{2}$ Department of Applied Biology and Biotechnology, Enugu State University of Science and Technology, Enugu, Nigeria.

${ }^{3}$ Department of Applied Biology and Biotechnology, Enugu State University of Science and Technology, Enugu, Nigeria.

Cite this article:

Josephine C.O., Ethel-Doris N.U., Victor S.N. (2021), Seasonal Larval Abundance of the Blackfly, Simulium damnosum Complex and the Physico-chemical Properties of their Breeding Sites in Oji River System, Enugu State, Nigeria. African Journal of Biology and Medical Research 4(3), 59-68. DOI: 10.52589/AJBMR7P1KWJLZ.

\section{Manuscript History \\ Received: 4 June 2021 \\ Accepted: 30 June 2021 \\ Published: 12 July 2021}

Copyright $\odot 2020$ The Author(s). This is an Open Access article distributed under the terms of Creative Commons Attribution-NonCommercialNoDerivatives 4.0 International (CC BY-NC-ND 4.0), which permits anyone to share, use, reproduce and redistribute in any medium, provided the original author and source are credited.
ABSTRACT: Seasonal larval abundance of the blackfly, Simulium damnosum complex, and the physico-chemical properties of their breeding sites in Oji river system was carried out, with the aim of finding out the season that promotes the breeding of $S$. damnosum complex and the effect of the physicochemical properties of the breeding sites of $S$. damnosum complex on larval abundance. Larvae of $S$. damnosum complex were collected monthly from forty-eight (48) breeding sites in four sampling units for three years, in dry and wet seasons. The physico-chemical properties of the breeding sites of S. damnosum complex studied were copper, dissolved oxygen, magnesium, nitrate, $\mathrm{pH}$, phosphate, potassium, temperature, and water velocity. A total of six hundred and ninety one (691) larvae of $S$. damnosum complex were collected in the Oji river system in both seasons. Wet season catch was more and comprised $82 \%$ of the total catch, while dry season catch comprised $18 \%$ of the total catch. Dry and wet seasons catches in the sampling units were found to differ statistically. All the physico-chemical properties of the breeding sites of $S$. damnosum complex determined showed positive correlations with total larval abundance in both seasons, except copper which showed no correlation with total larval abundance in the dry season. Wet season promotes larval abundance of $S$. damnosum complex, and the physico-chemical properties of the breeding sites of $S$. damnosum complex play some roles (in varying degrees) in larval development.

KEYWORDS: Simulium, Physico-Chemical Properties, Season, Larval Abundance. 


\section{INTRODUCTION}

The blackfly, Simulium damnosum complex, is the vector of Onchocerca volvulus, the causative agent of river blindness (onchocerciasis) in West Africa. Onchocerciasis constitutes serious public-health and socio-economic problems in many rural parts of the world including Nigeria (Adeleke et al., 2010). Nigeria is one of the most onchocerciasis endemic countries in the world and accounts for one quarter of the global onchocerciasis infection (Oyibo \& Fagbenro, 2003). The disease causes significant morbidity, psychosocial problems (Ubachukwu, 2001) with reduced agricultural productivity in populations affected by the disease (Ubachukwu \& Anya, 2001). In West Africa, including Nigeria, S. damnosum complex is found breeding in rapid sections of rivers and streams wider than 4 metres (Crosskey, 1990). The prevalence of infections could be attributed to the fact that many rivers and streams with favourable breeding sites abound in the affected areas and local farming practices make Simulium-human contact easy (Akogun \& Onwuliri, 1991), (Abdullahi \& Oyeyi, 2003).

The abundance of the $S$. damnosum complex varies with season. Adeleke et al. (2011) reported high populations of $S$. damnosum complex in wet season while low populations of the $S$. damnosum complex were reported in dry season by Ugwuanyi et al. (2015) and Ibeh et al. (2007).

The physico-chemical properties of the breeding sites of the $S$. damnosum complex are known to be correlated with the distribution of different species of blackflies (Crosskey, 1990). Among the physico-chemical properties governing the existence of breeding places are dissolved oxygen, adequate water velocity which is linked to food supply and the presence of suitable supports. Factors like $\mathrm{pH}$ and temperature of a river play some roles in the breeding of the $S$. damnosum complex (Grunewald, 1981).

Members of the $S$. damnosum complex in West Africa have not been found breeding in rivers with high levels of nitrate $\left(\mathrm{NO}_{3}{ }^{-}\right)>0.5 \mathrm{mg} / \mathrm{l}$, water velocities of $<0.4$ or $>2.4 \mathrm{~m} / \mathrm{s}$ and water temperatures lower than $16.8^{\circ} \mathrm{C}$ or greater than $33^{\circ} \mathrm{C}$. S. damnosum complex only breeds in water with relatively high oxygen saturations $>75 \%$ (Grunewald, 1981). Maximum water velocities of $2.8 \mathrm{~m} / \mathrm{s}$ (Ibeh et al., 2007) and $2.5 \mathrm{~m} / \mathrm{s}$ (Adeleke et al., 2011) were recorded in breeding sites positive for the larvae of $S$. damnosum complex, while Opara and Fagbemi (2005) reported water velocity range of $0.1-5.6 \mathrm{~m} / \mathrm{s}$ in breeding sites that supported the breeding of $S$. damnosum complex. The observation of Opara and Fagbemi was remarkable because it not only extends both the upper limit and lower limits for the velocities of water supporting breeding of $S$. damnosum complex but also the upper limit of Simuliidae as a whole, which was previously recorded at $0.05-3.5 \mathrm{~m} / \mathrm{s}$ (Crosskey, 1990). S. damnosum complex was found breeding in rivers with high levels of ammonia (but always $<1 \mathrm{mg} / \mathrm{l}$ ) except on one occasion when an unexplained measurement of approximately $6 \mathrm{mg} / \mathrm{l}$ was recorded (Opara \& Fagbemi, 2005).

The minimum and maximum dissolved oxygen values for waters that supported the breeding of $S$. damnosum complex were $6.5 \mathrm{mg} / 1$ and $7.4 \mathrm{mg} / \mathrm{l}$ respectively (Ibeh et al., 2007). Adeleke et al. (2011) reported mean dissolved oxygen of $7.2 \mathrm{mg} / \mathrm{l}$, mean values of nitrate- $0.12 \mathrm{mg} / \mathrm{l}$ and copper $-0.04 \mathrm{mg} / \mathrm{l}$ in breeding sites positive for the larvae of $S$. damnosum complex. Different pH ranges 5.6-7.0 (Grunewald, 1981), 5.6-5.9 (Onyenwe et al., 2007), 6.5-7.9 (Mafuyai et al., 1996; Bassey, 1998) and 6.4-8.7 (Ibeh et al., 2007) were recorded in breeding sites positive for the larvae of $S$. damnosum complex. 
Knowledge of the seasonal distribution of vectors and the micro-environmental conditions of the breeding sites of vectors helps in understanding why some vectors are more abundant in a particular area and season. It is therefore imperative that the seasonal abundance of $S$. damnosum complex and the physico-chemical properties of their breeding sites, which influence their breeding, are properly understood.

Oji river system is a big water body that supports the breeding of $S$. damnosum complex, but little is known about the seasonal larval abundance of $S$. damnosum complex and the physicochemical properties of their breeding sites.

This study therefore aims at understanding the seasonal larval abundance of $S$. damnosum complex and the physico-chemical properties of their breeding sites which influence their breeding. This will help in a rational design for a successful control of onchocerciasis in Oji river LGA and its environs.

\section{MATERIALS AND METHODS}

\section{Study Area}

The study area runs along the Oji river system in Oji-river Local Government Area (L.G.A.) of Enugu State, southeast Nigeria. Oji-river LGA is a semi-urban area located in the rainforest zone of southeast Nigeria. The geographical coordinates are $06^{\circ} 16^{\prime} \mathrm{N} 07^{\circ} 16^{\prime} \mathrm{E}$. There are two seasons: the wet (April-October) and the dry (November-March) seasons. The wet season has two rainfall peaks in July and September with a dry spell in August.

Four sampling units were selected along the Oji river system for the search for larvae of the Simulium damnosum complex. These were Adu-Achi $\left(06^{\circ} 19^{\prime} \mathrm{N} 07^{\circ} 34^{\prime} \mathrm{E}\right)$, Ahani-Achi $\left(06^{\circ} 20^{\prime} \mathrm{N} 07^{\circ} 32^{\prime} \mathrm{E}\right)$, Oji-urban $\left(06^{\circ} 26^{\prime} \mathrm{N} 07^{\circ} 27^{\prime} \mathrm{E}\right)$ and Okwe, Ugwuoba $\left(06^{\circ} 27^{\prime} \mathrm{N} 07^{\circ} 25^{\prime} \mathrm{E}\right)$.

\section{Search for the larvae of $S$. damnosum complex.}

Larval searches were carried out in twelve breeding sites in each sampling unit and altogether, forty-eight (48) breeding sites were extensively searched for the larvae of $S$. damnosum complex in the four sampling units monthly for three years (November 2015 - August 2018), November-March for the dry season and April-August for the wet season.

Simulium larvae attach themselves on submerged vegetation. Larval search therefore involved examining all the submerged life and dead vegetation in the breeding sites and all larvae found were picked using fine forceps and preserved in universal bottles containing cold Carnoy's solution (absolute ethanol and glacial acetic acid mixture of 3:1v/v). Water from the breeding sites were collected with $200 \mathrm{ml}$ containers during larval search. The bottles and the $200 \mathrm{ml}$ containers were carefully labeled with the names of the breeding site and sampling unit where the larvae and water were collected, before taking them to the laboratory. The larvae were identified morphologically under a dissecting microscope while the water samples were used for the determination of the concentration of copper, magnesium, nitrate, phosphate and potassium. 


\section{Morphological identification of S. damnosum complex larvae}

The larvae were examined under a dissecting microscope to ensure that they all belonged to $S$. damnosum complex and not other Simuliid flies. A diagnostic feature of S. damnosum complex larvae is the possession of protruding dorsal tubercles (Crosskey, 1960); presence of protruding dorsal tubercles was then used to isolate all S. damnosum complex larvae.

\section{Determination of the physico-chemical properties of the breeding sites of $S$. damnosum complex.}

Dissolved oxygen (DO) concentration and temperature of the breeding sites of S. damnosum complex were measured on site using Hanna battery powered dissolved oxygen and temperature meter (HI 70442), while $\mathrm{pH}$ was measured with a Hanna battery powered $\mathrm{pH}$ meter (HI 7007).

Water velocity was determined on site using the float method as described by Herschy (1995). This method involved placing a stick of two meters $(2 \mathrm{~m})$ long horizontally in the breeding site and releasing a cork at one end of the stick which was allowed to drift with the water to cover the $2 \mathrm{~m}$ distance of the stick. With a stopwatch, the time (T) taken for the cork to float from the point of release to the end of the stick ( $2 \mathrm{~m}$ distance) was recorded. Three successive measurements (T1, T2, and T3) were taken. The water velocity in $\mathrm{m} / \mathrm{s}$ was determined by the formula: Water velocity $=$ Distance $(\mathrm{L})$ in meters $\times 3$ measurements $\div$ mean of $\mathrm{T} 1+\mathrm{T} 2+\mathrm{T} 3$ in seconds.

The concentration of copper, magnesium, nitrate, phosphate and potassium in water from breeding sites was determined in the laboratory using an ultra violet (UV) visible spectrophotometer (Spectrum lab 752s) as adopted by Association of Official Analytical Chemists (AOAC, 2005).

\section{Data analysis}

The data obtained from the studies were analyzed using Statistical Package for Social Sciences (SPSS version 21.0). One-way Anova was used to test the total larval abundance of $S$. damnosum complex in dry and wet seasons, while correlation/regression analysis was used to test the effects of the physico-chemical properties of the breeding sites on total larval abundance in dry and wet seasons. Statistical significance was set at $\mathrm{P}<0.05$.

\section{RESULTS}

A total of $(n=691)$ larvae of $S$. damnosum complex were collected across the four sampling units in the study area. The seasonal larval abundance shows that higher numbers of larvae (n $=565)$ representing $81.77 \%$ of the total catch were collected in the wet season while $(n=126)$ representing $18.23 \%$ of the total catch were collected in the dry season. The difference in the total larval abundance of the $S$. damnosum complex collected in wet and dry seasons was statistically significant $(\mathrm{P}=0.005)($ Table $\mathrm{I})$. 
Table I: Total larval abundance of $S$. damnosum complex in dry and wet seasons

\begin{tabular}{|c|c|c|c|}
\hline Sampling unit & Wet season 'n' (\%) & Dry season 'n' (\%) & Total 'n' (\%) \\
\hline Adu-Achi & $176(31.15)$ & $41(32.54)$ & $217(31.40)$ \\
\hline Ahani-Achi & $159(28.14)$ & $38(30.16)$ & $197(28.51)$ \\
\hline Oji-urban & $66(11.68)$ & $20(15.87)$ & $86(12.45)$ \\
\hline Okwe, Ugwuoba & $164(29.03)$ & $27(21.43)$ & $191(27.64)$ \\
\hline Total ‘n' (\%) & $565(81.77)$ & $126(18.23$ & $691(100)$ \\
\hline
\end{tabular}

Higher larval abundance of $S$. damnosum complex was recorded in the months of the wet season than in the months of the dry season. In the wet season, the larval abundance recorded in April to June increased progressively but dropped in July and August. In the dry season, the highest larval abundance recorded was in November followed by February, but reduced in December, January and March (Figure 1).

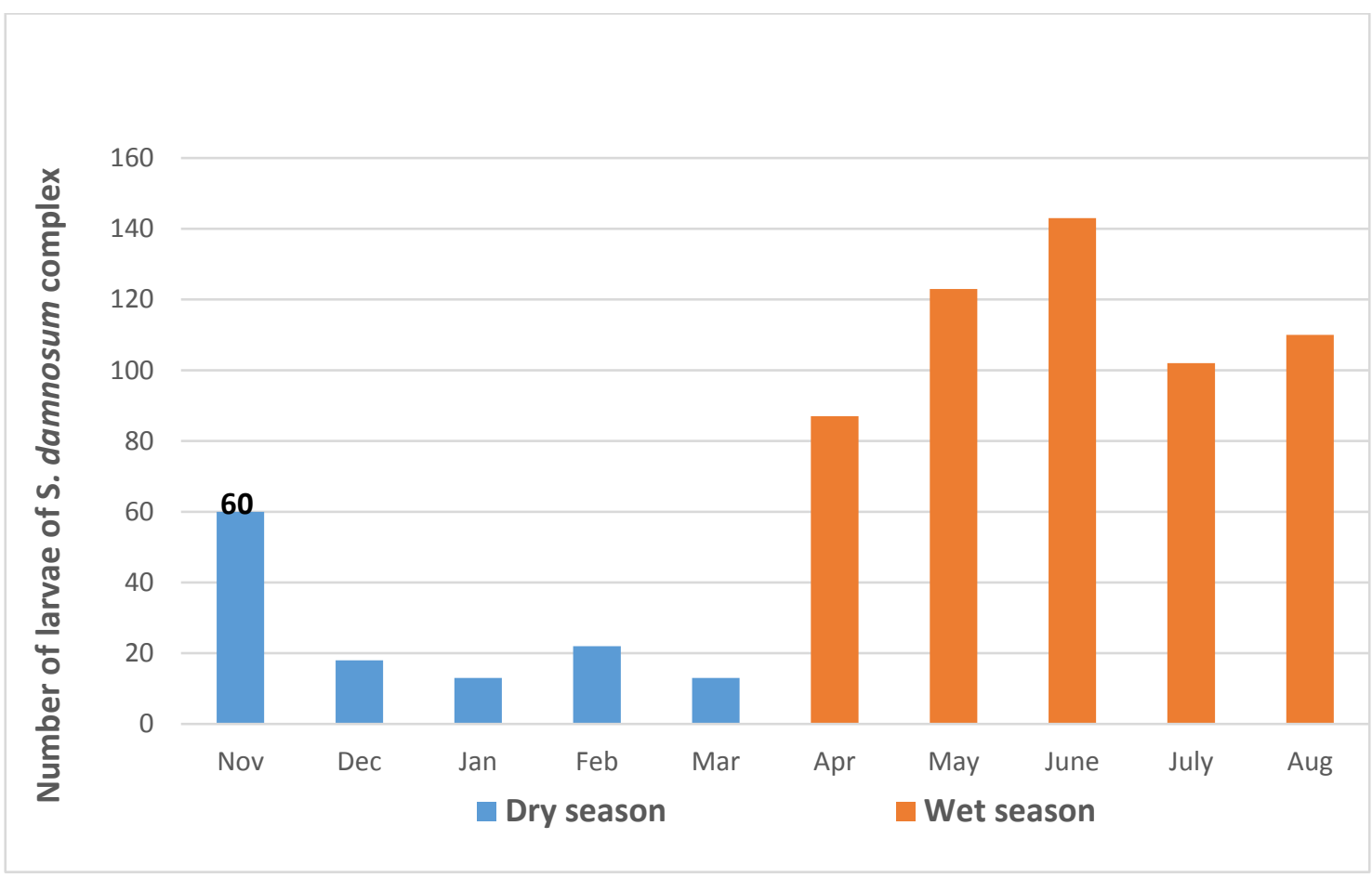

Figure 1: Monthly/seasonal larval abundance of $S$. damnosum complex in the study area

Mean values of dissolved oxygen and water velocity varied in the dry and wet seasons with the wet season values higher than those of the dry season. Mean values of $\mathrm{pH}$ and temperature were within the same range in both seasons. Mean values of copper, nitrate, phosphate and potassium were small with the wet season values higher than those of the dry season. Mean values of magnesium varied in the dry and the wet seasons with the wet season values higher than those of the dry season (Table II). 
African Journal of Biology and Medical Research

ISSN: 2689-534X

Volume 4, Issue 3, 2021 (pp. 59-68)

www.abjournals.org

Table II: Mean values of physico-chemical properties of the breeding sites and total larval abundance of $S$. damnosum complex in the sampling units in dry and wet seasons

\begin{tabular}{|c|c|c|c|c|c|}
\hline \multirow{2}{*}{$\begin{array}{c}\text { Physico- } \\
\text { chemical } \\
\text { parameters }\end{array}$} & \multirow[b]{2}{*}{ Season } & \multicolumn{4}{|c|}{ Sampling units } \\
\hline & & Adu-Achi & $\begin{array}{l}\text { Samp } \\
\text { Ahani-Achi }\end{array}$ & \multicolumn{2}{|c|}{ Okwe, Ugwuoba } \\
\hline Dissolved & Dry & $6.47 \pm 0.15$ & $6.52 \pm 0.14$ & $6.40 \pm 0.13$ & $6.44 \pm 0.14$ \\
\hline oxygen $(\mathrm{mg} / \mathrm{l})$ & Wet & $7.27 \pm 0.14$ & $7.29 \pm 0.14$ & $7.27 \pm 0.14$ & $7.24 \pm 0.14$ \\
\hline & Dry & $7.42 \pm 0.11$ & $7.09 \pm 0.11$ & $7.02 \pm 0.11$ & $7.06 \pm 0.11$ \\
\hline $\mathrm{pH}$ & Wet & $7.09 \pm 0.14$ & $7.10 \pm 0.12$ & $7.05 \pm 0.13$ & $7.21 \pm 0.13$ \\
\hline \multirow{2}{*}{$\begin{array}{l}\text { Temperature } \\
\left({ }^{\circ} \mathrm{C}\right)\end{array}$} & Dry & $25.96 \pm 0.17$ & $26.06 \pm 0.15$ & $26.11 \pm 0.17$ & $26.09 \pm 0.14$ \\
\hline & Wet & $25.16 \pm 0.14$ & $25.60 \pm 0.18$ & $25.64 \pm 0.16$ & $25.38 \pm 0.17$ \\
\hline \multirow{2}{*}{$\begin{array}{l}\text { Water velocity } \\
(\mathrm{m} / \mathrm{s})\end{array}$} & Dry & $1.66 \pm 0.12$ & $1.65 \pm 0.12$ & $1.64 \pm 0.10$ & $1.64 \pm 0.10$ \\
\hline & Wet & $2.47 \pm 0.13$ & $2.45 \pm 0.12$ & $2.43 \pm 0.13$ & $2.43 \pm 0.13$ \\
\hline \multirow[t]{2}{*}{ Copper (mol/l) } & Dry & $0.18 \pm 0.01$ & $0.19 \pm 0.02$ & $0.17 \pm 0.01$ & $0.22 \pm 0.01$ \\
\hline & Wet & $0.23 \pm 0.02$ & $0.23 \pm 0.01$ & $0.22 \pm 0.01$ & $0.22 \pm 0.01$ \\
\hline \multirow{2}{*}{$\begin{array}{l}\text { Magnesium } \\
(\mathrm{mol} / \mathrm{l})\end{array}$} & Dry & $2.41 \pm 0.12$ & $2.43 \pm 0.12$ & $2.43 \pm 0.11$ & $2.42 \pm 0.11$ \\
\hline & Wet & $2.58 \pm 0.12$ & $2.54 \pm 0.12$ & $2.50 \pm 0.13$ & $2.46 \pm 0.12$ \\
\hline \multirow[t]{2}{*}{ Nitrate $(\mathrm{mol} / \mathrm{l})$} & Dry & $0.18 \pm 0.01$ & $0.19 \pm 0.01$ & $0.18 \pm 0.01$ & $0.18 \pm 0.01$ \\
\hline & Wet & $0.22 \pm 0.01$ & $0.21 \pm 0.01$ & $0.22 \pm 0.01$ & $0.21 \pm 0.01$ \\
\hline \multirow{2}{*}{$\begin{array}{l}\text { Phosphate } \\
(\mathrm{mol} / \mathrm{l})\end{array}$} & Dry & $0.20 \pm 0.01$ & $0.20 \pm 0.01$ & $0.19 \pm 0.01$ & $0.19 \pm 0.01$ \\
\hline & Wet & $0.21 \pm 0.01$ & $0.22 \pm 0.01$ & $0.21 \pm 0.01$ & $0.22 \pm 0.01$ \\
\hline \multirow{2}{*}{$\begin{array}{l}\text { Potassium } \\
(\mathrm{mol} / \mathrm{l})\end{array}$} & Dry & $0.17 \pm 0.01$ & $0.17 \pm 0.01$ & $0.17 \pm 0.01$ & $0.17 \pm 0.01$ \\
\hline & Wet & $0.22 \pm 0.01$ & $0.21 \pm 0.01$ & $0.22 \pm 0.01$ & $0.22 \pm 0.01$ \\
\hline $\begin{array}{l}\text { Total larval } \\
\text { abundance }\end{array}$ & $\begin{array}{l}\text { Dry } \\
\text { Wet }\end{array}$ & $\begin{array}{c}41 \\
176\end{array}$ & $\begin{array}{c}38 \\
159\end{array}$ & $\begin{array}{l}20 \\
66\end{array}$ & $\begin{array}{c}27 \\
164\end{array}$ \\
\hline
\end{tabular}

There was non-significant $(\mathrm{P}>0.05)$ positive correlation between total larval abundance and mean values of dissolved oxygen, $\mathrm{pH}$, temperature, water velocity, magnesium, nitrate and phosphate in the dry and the wet seasons. Mean values of copper in the dry season were nonsignificant $(\mathrm{P}>0.05)$ and no correlation $(\mathrm{r}=0)$ with total larval abundance while the mean values in the wet season showed non-significant positive correlation with total larval abundance. Mean values of potassium in the dry season showed significant positive correlation $(\mathrm{P}=0.033)$ while the wet season values showed non-significant positive correlation with total larval abundance (Table III). 
Table III: Correlation coefficients and their levels of significance for total larval abundance of $S$. damnosum complex against mean values of physico-chemical properties of their breeding sites in dry and wet seasons.

\begin{tabular}{|c|c|c|c|c|c|c|}
\hline $\begin{array}{l}\text { Physico-chemical } \\
\text { properties }\end{array}$ & $\begin{array}{r}\text { DF } \\
\text { R-coefficient }\end{array}$ & $\begin{array}{l}\text { Y SEAS } \\
\text { P-value }\end{array}$ & $\begin{array}{l}\text { N } \\
\text { P v alpha }\end{array}$ & $\begin{array}{r}\text { WET S } \\
\text { R-coefficient }\end{array}$ & $\begin{array}{r}\text { EASON } \\
\text { P-value }\end{array}$ & P v alpha \\
\hline $\begin{array}{l}\text { Dissolved oxygen } \\
(\mathrm{mg} / \mathrm{l})\end{array}$ & 0.8553 & 0.152 & $\mathrm{P}>0.05$ & 0.1045 & 0.888 & $P>0.05$ \\
\hline $\mathrm{pH}$ & 0.7577 & 0.281 & $\mathrm{P}>0.05$ & 0.5683 & 0.450 & $P>0.05$ \\
\hline Temperature $\left({ }^{\circ} \mathrm{C}\right)$ & 0.8526 & 0.145 & $\mathrm{P}>0.05$ & 0.6914 & 0.296 & $\mathrm{P}>0.05$ \\
\hline $\begin{array}{l}\text { Water velocity } \\
(\mathrm{m} / \mathrm{s})\end{array}$ & 0.9109 & 0.092 & $P>0.05$ & 0.5995 & 0.415 & $\mathrm{P}>0.05$ \\
\hline Copper $(\mathrm{mol} / \mathrm{l})$ & 0 & 0.657 & $\mathrm{P}>0.05$ & 0.5982 & 0.451 & $\mathrm{P}>0.05$ \\
\hline Magnesium (mol/l) & 0.6567 & 0.364 & $\mathrm{P}>0.05$ & 0.3287 & 0.724 & $\mathrm{P}>0.05$ \\
\hline Nitrate $(\mathrm{mol} / \mathrm{l})$ & 0.4446 & 0.631 & $\mathrm{P}>0.05$ & 0.4615 & 0.483 & $\mathrm{P}>0.05$ \\
\hline Phosphate (mol/l) & 0.9478 & 0.064 & $\mathrm{P}>0.05$ & 0.4615 & 0.601 & $\mathrm{P}>0.05$ \\
\hline Potassium (mol/l) & 0.1974 & 0.033 & $\mathrm{P}<0.05$ & 0.2335 & 0.296 & $\mathrm{P}>0.05$ \\
\hline
\end{tabular}

\section{DISCUSSION}

There was seasonal variation in larval abundance of the $S$. damnosum complex in the study area. About eighty-two percent ( $82 \%$ ) of larvae of $S$. damnosum complex were collected in the wet season while eighteen percent $(18 \%)$ were collected in the dry season. The total larval abundance in the wet season differed significantly $(\mathrm{P}=0.005)$ at $0.05 \%$ from that of the dry season (Table I). This finding is consistent with the reports of Adeleke et al. (2011) where more populations of $S$. damnosum complex were collected in the wet season than in the dry season. The progressive increase in larval abundance in April to June (Figure 1) could be attributed to rainfall as these months correspond to periods when there was enough rainfall, which caused an increase in the volume of water that increased the force at the breeding sites, leading to optimal reproduction of Simulium flies. However, the drop in larval abundance observed in July and August could be attributed to heavy rainfall observed in these months, which washed away some of the Simulium larvae. Heavy rainfall usually caused the washing away of the larvae of S. damnosum complex (Hashiguishi et al., 1981). The low larval abundance from November to March could be attributed to little or no rainfall as these months correspond to periods when there were little or no rains, which reduced the volume of water that reduced the force at the breeding sites, leading to non-optimal reproduction of the Simulium flies.

The results of the physico-chemical properties obtained in the present study (Table II) are within the range of the values reported in a study by Adeleke et al. (2011) who recorded mean values of dissolved oxygen, water velocity, $\mathrm{pH}$ and temperature as $7.2 \pm 1.73 \mathrm{mg} / 1,2.5 \pm$ $0.24 \mathrm{~m} / \mathrm{s}, 7.0$, and $26.2^{\circ} \mathrm{C}$ respectively for breeding sites positive for the larvae of $S$. damnosum complex. The results are also within the range of the values recorded in a study by Ibeh et al. (2007) where the values of dissolved oxygen, water velocity, $\mathrm{pH}$ and temperature recorded 
were $6.5-7.4 \mathrm{mg} / \mathrm{l}, 1.7-2.8 \mathrm{~m} / \mathrm{s}, 6.4-8.7$ and $24.0-28.0^{\circ} \mathrm{C}$ respectively for breeding sites positive for the larvae of $S$. damnosum complex.

Mean values of copper and nitrate recorded in this study agree with that of Adeleke et al. (2011) who recorded mean values of nitrate $-0.12 \mathrm{mg} / \mathrm{l}$ and copper- $0.04 \mathrm{mg} / \mathrm{l}$ in breeding sites positive for the larvae of $S$. damnosum complex. The mean values of copper, nitrate, phosphate and potassium recorded in both the dry and the wet seasons in this study could be regarded as small and could not have contributed much to the increase or decrease in larval abundance in both seasons. Mineral elements are required in small quantities and are essential for insect nutrition and their deficiency can have a significant negative effect on insect biology even if the major nutrient groups are present in adequate quantities and ratios in their diet (Cotez Ortiz \& Jullien, 2016).

High mean values of magnesium recorded in the breeding sites in both seasons could be due to the existence of rocks in some of the sampling units. The slight increase in the mean values of magnesium, copper, nitrate, phosphate and potassium observed in the wet season may be due to erosion which washed away some of the mineral elements from the river banks and nearby farmlands into the river.

The positive correlations observed between the physico-chemical properties and the total larval abundance (Table III) implies that these parameters play different roles (in varying degrees) in the breeding of $S$. damnosum complex.

This study has revealed that wet seasons promote larval abundance of $S$. damnosum complex and the physico-chemical properties of the breeding sites of $S$. damnosum complex influence their breeding.

This finding would help in the development of predictive population models, which may be useful in the planning and execution of successful control of onchocerciasis in Oji-river LGA and its environs.

Further studies are recommended on other ecological parameters that could influence the breeding of $S$. damnosum complex in the study area in order to establish a comprehensive data on the ecological parameters that influence the breeding of $S$. damnosum complex in the area.

\section{Acknowledgement}

The authors are grateful to the tour guides from the communities where the sampling units were selected for their guide during larval search, using their good knowledge of the Oji river system. We thank the management of National Arbovirus and Vectors Research Centre, Enugu, Nigeria, for their logistics support in the conduct of this research. 


\section{REFERENCES}

Abdullahi, Y. M. and Oyeyi, T. I. (2003). Current status of Onchocerciasis in Tudun Wada Doguwa Local Government Area of Kano State. Nigerian Journal of Parasitology, 24:77-88.

Adeleke, M. A., Olaoye, I. K. and Ayanwale, A. S. (2010). Socio-economic implications of Simulium damnosum complex infestations in some rural communities in Odeda Local Government Area of Ogun State. J. Public Health Epidemiol. 2(5): 109-112.

Adeleke, M. A., Sam-Wobo, S. O., Olatunde, G. O., Akinwale, O. P., Ekpo, U. F. and Mafiana, C. F. (2011). Bioecology of Simulium damnosum Theobald complex along Osun river, South West Nigeria. Journal of Rural and Tropical Public Health, 10:39-43.

AOAC (Association of Official Analytical Chemists) (2005). Official Methods of Analysis of the Association of Analytical Chemists International. $18^{\text {th }}$ ed. Gaithersburg, MD U.S.A. Official Methods, 2005.08.

Akogun, O. B. and Onwuliri, C. O. (1991). Hyperendemic onchocerciasis in the Taraba valley of Gongola State (old Adamawa province), Nigeria. Annales de Parasitogie Humaine et Comparee, 6(1):22-26.

Bassey, S. A. (1998). Cytological studies and distribution of Simulium damnosum complex in Nigeria, Cameroon and Equatorial Guinea. PhD Thesis, Ahmadu Bello University, Zaria, Nigeria.

Cortez Ortiz, J. A. and Jullien, R. L. (2016). Insect Mass Production. Technologies in Insects as Sustainable Food Ingredients.

Crosskey, R. W. (1960). A taxonomic Study of the larvae of West African Simuliidae (Diptera: Nermatocera) with comments on the morphology of the larval blackfly head. Bulletin of the British Museum (Natural History) (Entomology) 10:1-74.

Crosskey, R. W. (1990). The Natural History of Blackflies. British Museum (Natural History), London: John Wiley and Sons. 156pp.

Grunewald, J. (1981). Hydro-chemical and Physical characteristics of the larval sites of the Simulium damnosum complex. In Laird, M. (Ed). Blackflies: The Future for Biological Methods in Integrated Control. Academic Press, London, 227-235.

Hashigushi, Y., Kawabata, M., Tramaka, I., Flores, O. C., Okasawa, T. and Recinos, M. M. (1981). Seasonal variation in the microfilarial skin density of Onchocerca volvulus and in the biting activity of Simulium species in Guatemala. Trans Royal Society Trop Med Hyg. 75:839-847.

Herschy, R. W. (1995). Streamflow measurements. CRC Press, Florida.

Ibeh, O. O., Nwoke, B. E. B. and Adegoke, J. A. (2007). Distribution and ecology of the breeding sites of Simulium damnosum s.l. in south eastern primary health zone of Nigeria. Nigerian Journal of Parasitology, 28:32-38

Mafuyai, H. B., Post, R. J., Vajime, C. G. and Molyneux, D. H. (1996). Cytotaxonomic identification of the Simulium damnosum complex (Diptera: Simuliidae) from Nigeria. Trop. Med. Int. Health, 1:775-785.

Onyenwe, E., Ubachukwu, P. O. and Post, R. J. (2007). Simulium sirbanum at a site in SE Nigeria. British Simuliid Group Bulletin, 28:17-21.

Opara, K. N. and Fagbemi, B. O. (2005). Physico-chemical indices of breeding sites of Simulium damnosum in the lower cross river basin, Nigeria. Journal of Environmental Science 17: 511-517. 
Oyibo, W. A. and Fagbenro, B. (1998). An evaluation of community compliance with annual ivermectin treatment of onchocerciasis in Patigi, Nigeria. East African Medical Journal, 75(4):234-239.

Ubachukwu, P. O. (2001). Studies on Epidemiology and Effects of Human Onchocerciasis on Productivity and Social Lives of Rural Communities in Uzo-Uwani Local Government Area of Enugu State, Nigeria. PhD Thesis, University of Nigeria Nsukka.

Ubachukwu, P. O. and Anya, A. O. (2001). Effects of Blackfly bites and manifestations of onchocerciasis in the productivity of farmers in Uzo-Uwani Local Government Area of Enugu State, Nigeria. Agro Science, 2(1):9-16.

Ugwuanyi, I. K., Eneanya, C. I., Nwaorgu, O. C., Aribodor, D. N., Mbanefo, E. C., Umeaneto, P. U., Egbuche, C. M. and Ugha C. N. (2015). Cytotaxonomic identification of Simulium damnosum complex (Diptera: Simuliidae) in Oji River area of Enugu State, Nigeria. Journal of Entomology and Zoology Studies, 3(3):34-39. 